\title{
Comics, Funny and Unfunny
}

\section{Paul Buhle}

Spain Rodriguez, My True Story (Seattle: Fantagraphics Books 1994)

Ho Che Anderson, King, I (Seattle: Fantagraphics Books 1993)

Howard Cruse, Stuck Rubber Baby (New York: Harper Perennial 1996)

This review begins with the personal admission of a social historian: comics have meant a great deal to my life. After Johnny Appleseed and Willie Mays, the biggest hero of my childhood was Harvey Kurtzman, the editor of Mad Comics (1952-55), from which the slicker Mad Magazine drew its themes, never treating them so sharply again. The early Mad's ruthless satire of commercial genres, its attack upon McCarthyism, and its frantic study of Middle American life has not been surpassed and on comic art ground probably cannot be surpassed, as R. Crumb has often lamented. Not many years after Kurtzman had given up his final magazine, Help! (staffed in part by Gloria Steinem), my own New Left magazine, Radical America, reached its circulation if not cerebral apex with Radical America Komiks (1969), the third "underground" comic, put together by Gilbert Shelton.

Various members of a remarkable seventies generation of popular artists - most of them since gone artistically silent because they could no longer sustain themselves drawing - have done more tc analyze popular life than any brief treatment can begin to elaborate. Like the most serious and talented of muralists and poster artists, their graphic scholarship has redefined, for me, what can be done in public history. None of these areas have found their scholars. But the scholarship of North American comic art, like the readership of graphic novels, remains noticeably slight and mainly adolescent.

Not much might reasonably be expected from comic artists along sustained scholarly-historical lines since they have received (unlike their counterparts in Europe, Latin America and Asia) so little support and encouragement. But that would be an erroneous assumption. Going back to the later 1960s and early 1970s, Jack Jaxon's treatment of Texas history was exemplary in its detail and historical accuracy. Larry Gonick's long running, multi-volume History of the Universe, including a separate history of the US, has had a genius for simplification and explanation along radical lines. Harvey Pekar's long-running American Splendor traces the origins of his ethnic Cleveland neighborhoods with excruciating sensitivity. Art Spiegelman continued his epic Maus in the pages of $A R C A D E$, a mid-seventies comic magazine (co-edited by Bill Griffith, later of syndicated Zippy) which featured an interpretation 
of art history as part of the package. (ARCADE, like Spiegelman's later highly-touted $R A W$, was a financial flop). Feminist artists like Trina Robbins and Sharon Kahn Rudahl made assorted seriously-funny contributions to women's history, in Wimmin's Comix and elsewhere. Likewise, a general radical treatment, The Underhanded History of America, was published as an issue of Radical America (written by Jim O'Brien and drawn by Nick Thorkelson).

In later years, among other experimenters with form, Ben Katchor achieved New Yorker renown with Cheap Novelties, a reflection upon Jewish street life in the vanished small-factory districts of Manhattan. It is easy to forget, even with R. Crumb's splendid rendition of Kafka in hand, that the "King of the Undergrounds" began thrilling the rest of us with careful drawings of vernacular Cleveland, already looking historically distant in 1968. Crumb had, after all, once been Pekar's roommate, and a contributor to Help! along with Gilbert Shelton. It was a small world after all. ${ }^{1}$

Spain Rodriguez has been in this world pretty much all along, yet sui generis among the crowd. His drawings of the revolutionary adventurer Trashman can be found in the earliest underground comics, and from the beginning, "Spain" (as he styles himself) has had a historical sensibility. My True Story is actually a collection of pieces from personal life and historical accounts, but it contains as much of the Spain story as he wants to reveal: a blue-collar kid from Buffalo languishing in the mid-1950s teen culture of gangs, Rock ' $n$ Roll (the only significant opportunity for interracial contact, or even proto-politics), rumbles, and a little class hatred. In the Afterword, he describes his brush with high culture - he went to art school - and his appreciation for Mexican muralists. By 1968, Spain was drawing for the East Village Other (whose comic spread, Gothic Blimp, was the first widely circulated vehicle for the group of new artists) and gets assigned to the Democratic Party convention in Chicago - where he gets to kick ass as an antiracist: definitely not peace-and-love vintage New Leftist.

In between, Spain joins and leaves the Progressive Labor Party (the New Left's earliest influential Maoists) and acquired an autodidact's knowledge of Left-wing history. In the second half of My True Story, simply called "History," stories of the Paris Commune, the Spanish Civil War, the siege of Leningrad, the air fight over Stalingrad, the fate of Stalin, and the "Hot Autumn" of 1970s Italian radicalism, are traced with a revolutionary fatalism that is both touching and hard as nails.

Ho Che Anderson comes from a different place entirely, the newly created traditions of the graphic novel (confined, for the most part, to superhero fare, with genre crime features as a familiar sideline) which are far more determinedly subjective and graphically postmodern. Dark splashes of images, occasional color splashes in selected panels, real photos worked in dada-like, in short almost everything (but the expensive total color of the old dime comic books; and sex, which is drawn more carefully after assorted busts of under- 


\section{Left History 5.2}

ground comics distributors) and anything imaginable. The result is certainly an interesting telling of Martin Luther King Jr.'s early life - although various key elements left out will rapidly spring to the minds of many readers (King's quiet connections with the Left, for instance) - but demanding and frustrating in ways unfamiliar to the comic reader. Anderson insists, in his introduction, that this is an interpretation not meant to be definitive (promised second and third volumes have not appeared). There's no doubting the honesty and integrity of the effort. Perhaps within the next decade, the form will establish itself; or perhaps it will fade (this seems more likely to me), one more experiment with political graphics looking for an elusive North American audience.

Howard Cruse has found that audience, thanks to niche marketing. He has been "the" gay underground comics artist since Gay Comix began in the 1980s, an anthology venture which he edited in its initial phase. Howard poured years of concentrated effort into this goal: Stuck Rubber Baby won the Eisner Award (named after Will Eisner, artist of the innovative 1940s strip, The Spirit), was named the Best Graphic Novel by United Kingdom Comic Art Awards, and took in nominations for the American Library Association's Gay and Lesbian Book award (and the Lambda Literary Award). Like Crumb and Katchor, his name appears in the New York Times (too rarely) as an important comic artist. Someday, if he may even make a living drawing!?

Stuck Rubber Baby bears an introduction by Tony Kushner - himself one of the most important American gay artists - and earns it in the closely-written, closely-drawn 200 plus pages. Cruse obviously draws upon his own experience of a Southern background to offer a bildungsroman during the 1960s and perhaps early 1970s in a middle sized Deep South town. His protagonist, a working class boy with a self-educated father, had early intimations of homosexual feelings and uncertain ambitions, went into the Army (as so many similar Southern boys black and white did and do) and came out to a changed world of shopping malls, the sexual revolution and African Americans no longer willing to accept the old ways.

In this charged atmosphere, he has a love affair with a college girl - in many ways the strongest character of the book - who is both a folk-singer and a radical campus leader. He also has a family consisting of folks at home, a slightly bohemian married sister and a deeply racist, conservative brother-inlaw. (This image really rings true for those of us with relatives in the Evangelical world.) But the most startling thing is the gay scene, which exists in clubs and of course bedrooms under the very nose of Bible Belt residents.

The narrative, which includes demonstrations, complex (sometimes interracial) intimate personal relations and a murder or two, defies summarization. Suffice it to say that our protagonist grows strong enough to accept his sexuality (he must go north to come out) and to act as morally as he can under the circumstances. It remains for an authentic Southerner, I think, to say whether Stuck Rubber Baby is absolutely true to life. It is true to its own purposes, as 
far more than an Out of the Closet story; it may be one of the best studies of social life with gay components at that time and place.

Comics, in short, are growing up. This critic said so in 1970, with great hopes for a consolidation of the technical and thematic advances that had been made. ${ }^{3}$ The audience was only there for a short period, and has not grown much since. But the potential remains, now more than ever.

\section{Paul Buhle \\ Brown University}

\footnotetext{
${ }^{1}$ Some of this story (and its background) is documented in Paul Buhle and Edmund Sullivan, eds., Images of American Radicalism (Hanover 1998), and in Leonard Rifas, "Underground Comics," in Mari Jo Buhle, Paul Buhle and Dan Georgakas, eds., Encyclopedia of the American Left, second edition, (New York 1998). Most of it is scarcely documented, although the periodical Comic World has abundant interviews and reviews.

${ }^{2}$ Thanks to Howard Cruse for e-mail on various matters. In the face of a tough job market for the historian-readers of Left History, it should be noted, for instance, that Crumb sells his oil paintings in France, Katchor is syndicated among alternative papers, Trina Robbins draws commercial comic characters, and perhaps only someone like Bill Griffith or Spiegelman (thanks to grants and showings) can make a living in the trade. ${ }^{3}$ Paul Buhle, "Komiks Kountermedia," in George Abbott White, ed., Literature in Revolution (New York 1973), the book reprinted from a 1970 issue of the journal TriQuarterly. I had the dubious honor of being accorded that year, in Playboy, the accolade of the "first serious critic of underground comix." I seem to have ceded that title sometime later.
} 